\title{
Policies for National Museum Management: Solutions and Development
}

\author{
Jarunee Incherdchai
}

\begin{abstract}
There are 41 national museums in Thailand. Since the Act on National Education of 1997, national museums have been expected to provide more educational services and facilities, but a lack of museum personnel and inadequate budgets remain big problems. Recently the decision was made to reduce the number of national museums, and the small-scale national museums, formerly monastery museums, have returned to being monastery museums. To improve the image of national museums, three pilot projects are undergoing: the first project is establishment of seven national museum storage units - a main central storage unit in Pathumthani Province and six regional national museum storage units -; the second project is renovation of the National Museum Bangkok; and the third project is development of the Kanchanaphisek National Museum which will represent all ethnic groups in Thailand.
\end{abstract}

\section{Background to National Museums in Thailand (Fine Arts Department, 2008)}

Looking back to 1874 , the first public museum originated at the Concordia Pavilion (Fig. 1) inside the Grand Palace and opened on the occasion of King Rama V's birthday celebrations (Fine Arts Department, 2008). The museum exhibited the royal collections of King Rama IV and other objects of general interest. Afterward, a special exhibition was opened regularly on His Majesty's birthday till 1887. It was transferred from the Palace to the Front Palace or "Wang Na," which had been the Palace of the Prince Successor, and was called the "Royal Museum at Wang Na" (Fig. 2) under the Museum Department, Ministry of Dhammakarn (Ministry of Education) (the former Ministry of Public Instruction, also in charge of religious affairs).

The management of the Royal Museum at Wang Na during the reign of King Rama V was progressive and systematic. The museum opened regularly on Wednesdays and Sundays from 10 am to 4 pm except on those days that shall fall on

J. Incherdchai $(\bowtie)$

Kanchanaphisek National Museum, Khlong 5 subdistrict, Khlong Luang district,

Pathumthani Province 12100, Thailand

e-mail: jajum@yahoo.com 

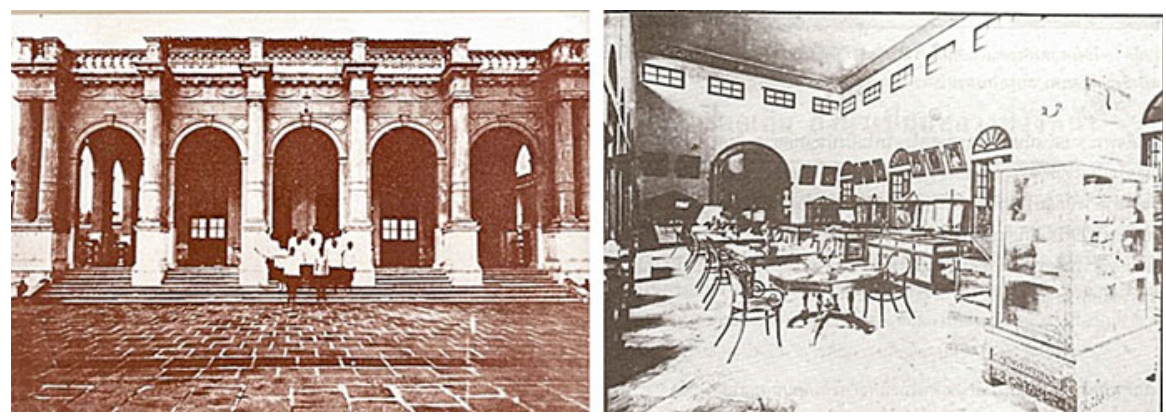

Fig. 1 The Royal Museum at the Concordia Pavilion, Royal Palace, during the reign of King Rama V
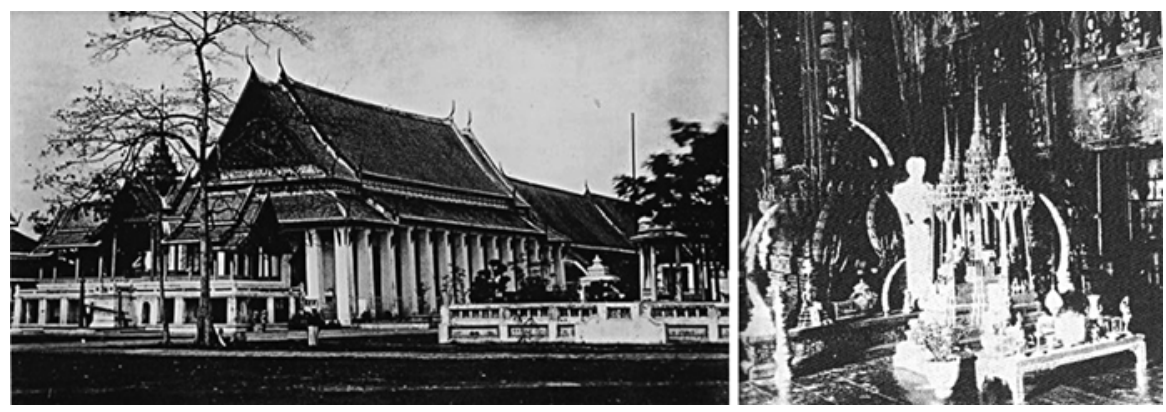

Fig. 2 The Buddhaisawan Chapel, a part of Royal Museum at Wang Na, during the reign of King Rama V

Siamese Sundays or Wan Phras. As the same time, the first museum located in the province was established; this was Ayutthaya Museum, modeled on other museums such as the monastery museums in Sukhothai and Nakhonpathom Provinces.

During the reign of King Rama VI, in 1912, museum was an important organization of the Fine Arts Department, which was under the direct auspices of His Majesty the King. There were more than 20 museums during the period and most of them were monastery museums. Prince Damrongrajanubhap was a key person running museum works until the subsequent reign. The status of museums was an institution to protect and preserve cultural heritage.

During the reign of King Rama VII, in 1925, the Royal Museum at Wang Na was changed to the Museum for Phranakhon (Fig. 3) by expanding the house of galleries inside other buildings of the palace. The public museum was opened formally on November 19, 1926. Under the Act on Establishment of the Museum for Phranakhon in 1926, more monastery museums in the provinces such as the Monastery Museum of Mahathat Phetchaburi, Monastery Museum of Phrathat Hariphunchai in Lamphun Province, and so on were built.

During the period of democracy, in 1934, the next museum act, i.e., the Act on Ancient Monuments, Objects of Art, Antiques and National Museums, 1934, was announced, the Museum for Phranakhon was changed to "National Museum 


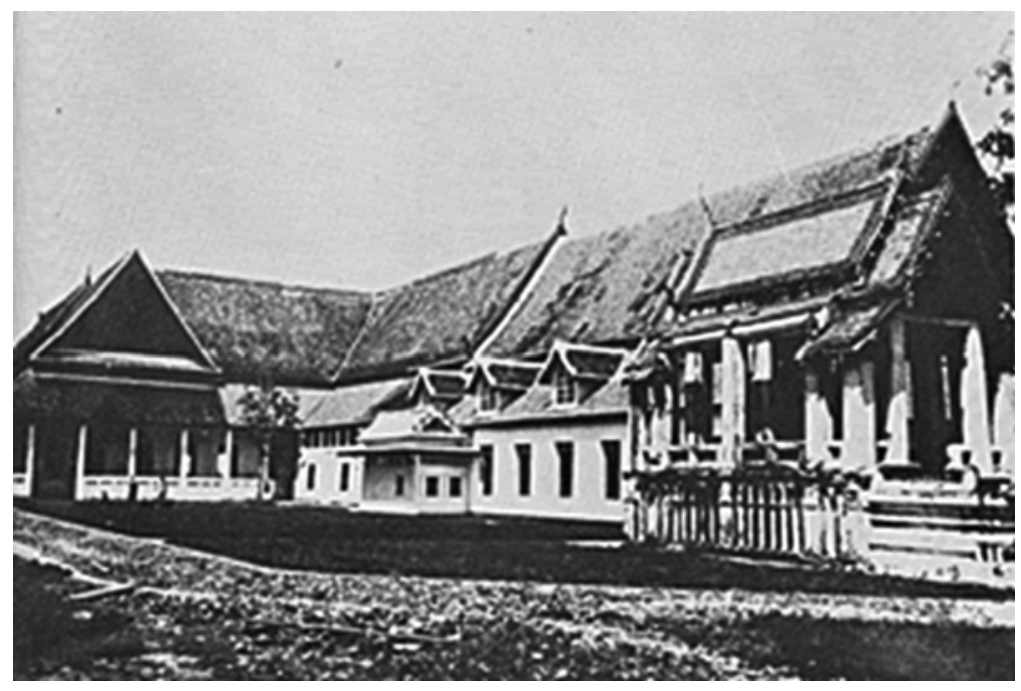

Fig. 3 Old Palace of Wang Na, as Museum for Phranakhon

Bangkok," and all museums established both before and after 1934, which were under the Fine Arts Department, now had the status of national museum.

\section{Role and Function of National Museums in Thailand}

The primary role of the museums was as a "reception hall" showing Siamese civilization to Westerners. Later, museums were a splendid place for appreciation and learning, as was King Rama V's intention. Anyhow, the protection, including the surveying, gathering, and collecting of cultural heritage, that is, ancient objects, was a major task led by King Rama VI. Museums such as the Royal Museum at Wang $\mathrm{Na}$, Ayutthaya Museum, Lopburi Museum, and Wat Mahathat Monastery Museum in Phetchaburi Province were places for keeping and preserving all national ancient objects.

The role of museums was extended to educational service in the following times, together with various national museums being set up, also according to the Act on Ancient Monuments, Objects of Art, Antiques and National Museums, 1934 (Fine Arts Department, 1998). During 1961-1974, national museums in Thailand underwent rapid growth because of the government's policy. A total 15 national museums together with 10 monastery museums were established in this period. Examples are as follows:

1. Chao Sam Phraya National Museum, Ayutthaya Province

2. Ramkhamhaeng National Museum, Sukhothai Province

3. U Thong National Museum, Suphanburi Province

4. New Building in the National Museum Bangkok 


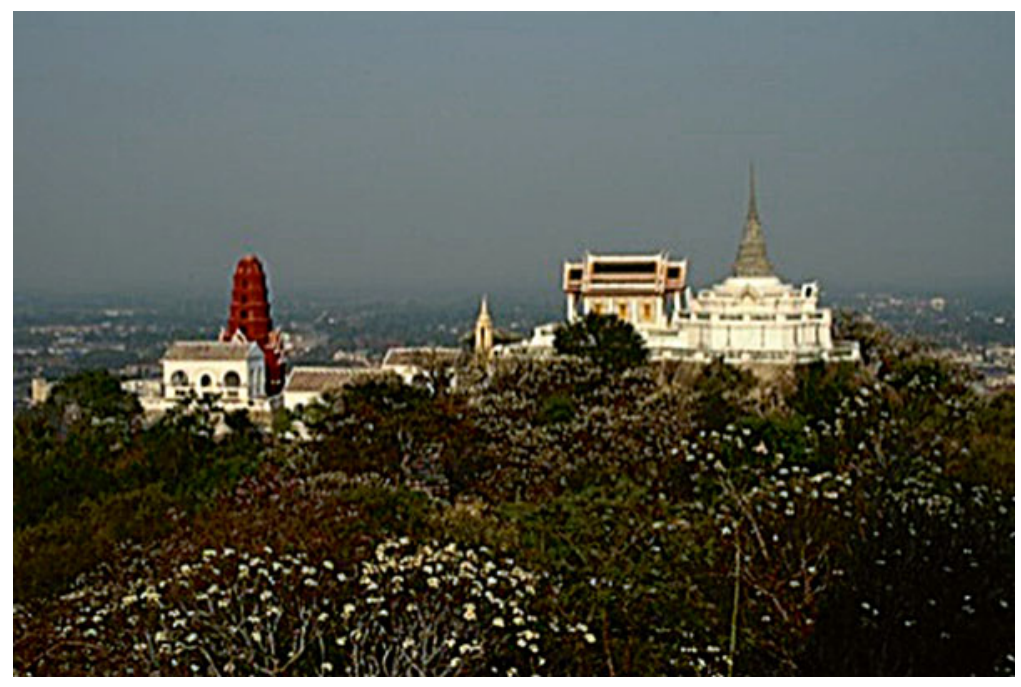

Fig. 4 Phanakhonkhiri National Museum, in Phetchaburi Province, old palace during the reign of King Rama V

5. Kamphaeng Phet National Museum, Kamphaeng Phet Province

6. Phrapathom Chedi National Museum, Nakhonpathom Province

7. Khon Kaen National Museum

8. Chiang Mai National Museum

9. Nakhon Si Thammarat National Museum

10. Ban Kao National Museum, Kanchanaburi Province

11. Ban Chiang National Museum, Udonthani Province

12. Phimai National Museum, Nakhonratchasima Province

13. Chiangsaen National Museum, Changrai Province

14. Hariphunchai National Museum, Lamphun Province (monastery museum)

15. Mahawerawong National Museum, Nakhoratchasima Province (monastery museum)

16. Inburi National Museum, Singburi Province (monastery museum)

17. Chainatmuni National Museum, Chainat Province (monastery museum)

18. Chaiya National Museum, Suratthani Province (monastery museum)

19. Matchimawat National Museum, Songkhla Province (monastery museum)

20. Phraphutthachinnarat National Museum, Phitsanulok Province (monastery museum)

During 1975-1995, the national museums started treating various different themes.

- Historical or memorial: Phanakhonkhiri National Museum (Old Palace) (Fig. 4), Phetchaburi Province and Silp Bhirasi Memorial, Bangkok.

- Contemporary art: The National Gallery, Bangkok (Fig. 5). 

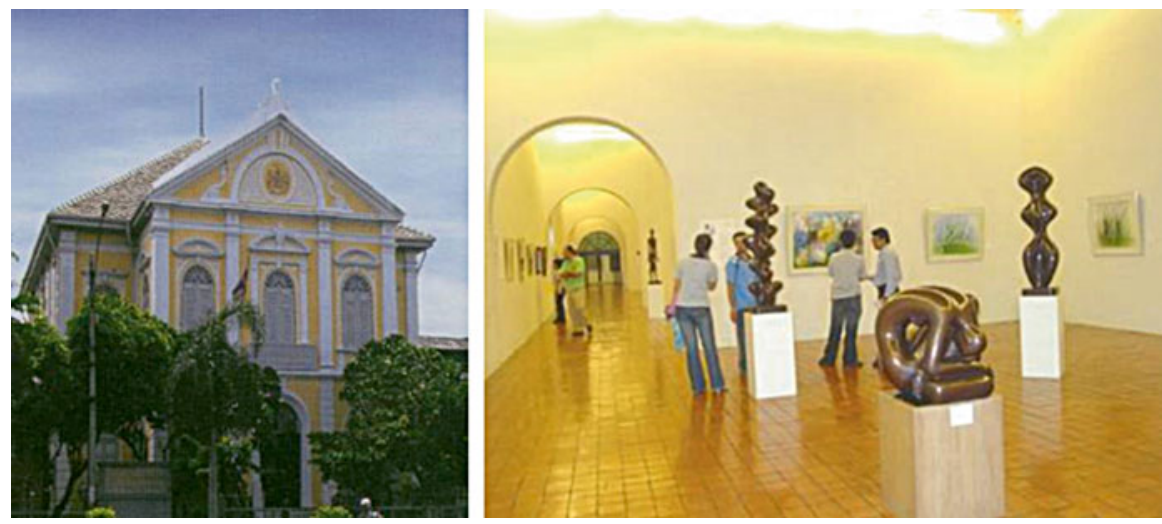

Fig. 5 The National Gallery, Bangkok
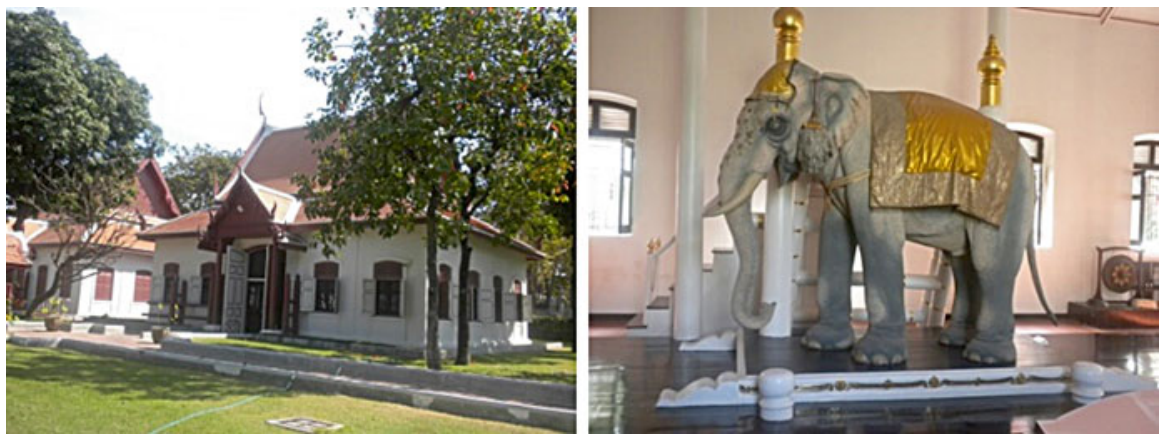

Fig. 6 The Royal Elephant National Museum in Bangkok

- Specialized museum: The Royal Barge National Museum in Bangkok, the Royal Elephant National Museum in Bangkok (Fig. 6), and the Thai Farmer National Museum in Suphanburi Province.

- City Museum: Ubonratchathani National Museum (Fig. 7), Surin National Museum, Nan National Museum, Ratchaburi National Museum, Suphanburi National Museum, and Roi-Et National Museum (Fine Arts Department, 2006).

Nowadays, there are 41 national museums over the whole country, caring for national heritage, ancient objects, art objects, and ethnographical objects, of which there are more than 300,000 pieces.

\section{Reasons for Developing National Museums}

According to the Act on National Education 1997, there are two main points related to museums. 


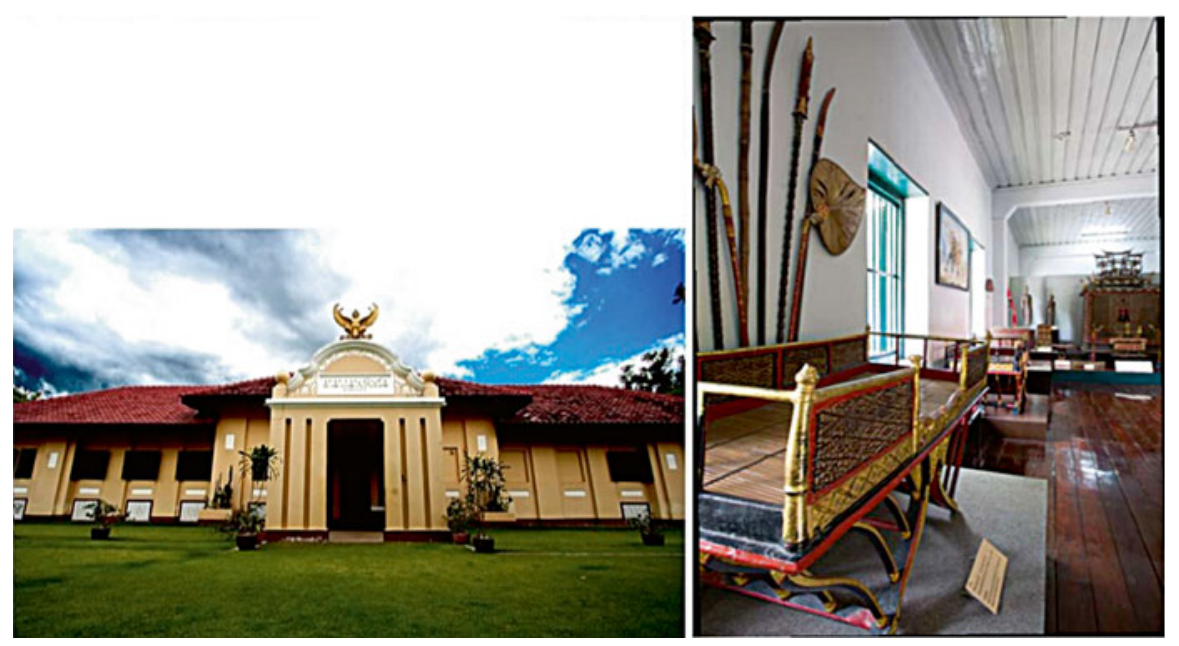

Fig. 7 Ubonratchathani National Museum

1. Museums are informal educational units.

2. A teacher has to lead a student to a museum.

For these reasons, national museums were expected to change their image and develop ways of presentation in the exhibition galleries, adding more educational services and facilities. A few national museums, of large scale, were able to approach the goal, but most of them could not depend on personnel and budget.

The 41 national museums can be divided into three levels or scales: large, medium, and small.

- Large-scale museums are mostly regional national museums: Chiang Mai National Museum, Ramkhamhaeng National Museum, Chaosamphraya National Museum, Somdet Phranarai National Museum, U Thong National Museum, Khonkaen National Museum, Phimai National Museum, Songkhla National Museum, and Nakhon si Thammarat National Museum. There are two national museums in the center: the National Gallery and Kanchanaphisek National Museum. The National Museum Bangkok is considered to be a special level.

- Medium-scale museums are mostly city museums: Ubonratchathani National Museum, Ratchaburi National Museum, Surin National Museum, Banchiang National Museum, Chandharakasem National Museum, Chumphorn National Museum, Suphanburi National Museum, and so on.

- Small-scale museums are all former monastery museums before transfer to becoming national museum units: Mahawerawong National Museum, Matchimawat National Museum, Inburi National Museum, Chainatmuni National Museum, and so on.

The lack of museum personnel is quite a big problem. Nowadays, there are approximately 90 curators working in the national museums. There are three, two, 
and one curator(s) for large, medium, and small scale respectively. Thai curators have to be museum manager, exhibitor, educator, and academic maker all at the same time, as well as sometimes conservator, without an academic degree in museum management, exhibition, and conservation. They have learnt by experience, through coaching, training, workshops, and studying by themselves. However, this is not always the case. A few curators "pass an exam," can run museum work, and approach the goal. Certainly, most curators aim to run their museum as head or director so as to save budget on academic research. That is to say, the Office of National Museums, Fine Arts Department, is nowadays lacking specialists in ancient objects and art objects including museology and museography.

Of course, the next problem is inadequate budget. The main part of the budget for the 41 national museums comes from the central government, through the Fine Arts Department, which is responsible for 26 divisions/offices concerned with preservation and promotion of the artistic and cultural heritage of the nation. In fact, museum operations definitely need a rather large budget for maintenance and modification. Many national museums have never changed their permanent exhibitions after formal opening to the public the first time, even the National Museum Bangkok. A few large national museums, such as Ramkhamhaeng National Museum, have been modified, but more than 15 years ago. Anyhow, there are at least five large national museums modified with new exhibitions, such as the U Thong National Museum, Songkhla National Museum, and Somdet Phranarai National Museum. The Nakhon Si Thammarat National Museum will be completed in 2020. Also, the Chiang Mai National Museum is now undergoing a modification project and planned to open in the next 2 years. It is unbelievable that the Chao Sam Phraya National Museum, in Ayutthaya Province, has never changed its exhibition since being opened to the public in 1963. Including the National Museum Bangkok, the project of renovation started in 2015. The duration of the project is 10 years, for archaeological excavation, reconstruction of monuments, and modification of permanent exhibitions, inside the old palace compound and inside two buildings, the Mahasurasinghanat and Praphat Phiphitthaphan buildings, where sculptural masterpieces of Thailand from the prehistoric period to the Ayutthaya period are housed.

However, more than ten national museums received budget supported by local government because of their uniqueness, such as the Phranakhon Khiri National Museum in Phetchaburi Province, Ban Chiang National Museum in Udonthani Province, and Kamphaengphet National Museum. Moreover, the Suphanburi National Museum is a good example of a museum receiving budget support from local government.

\section{Solutions and Development}

The solution to museum problems can be divided into two levels: the action level and the policy level. 

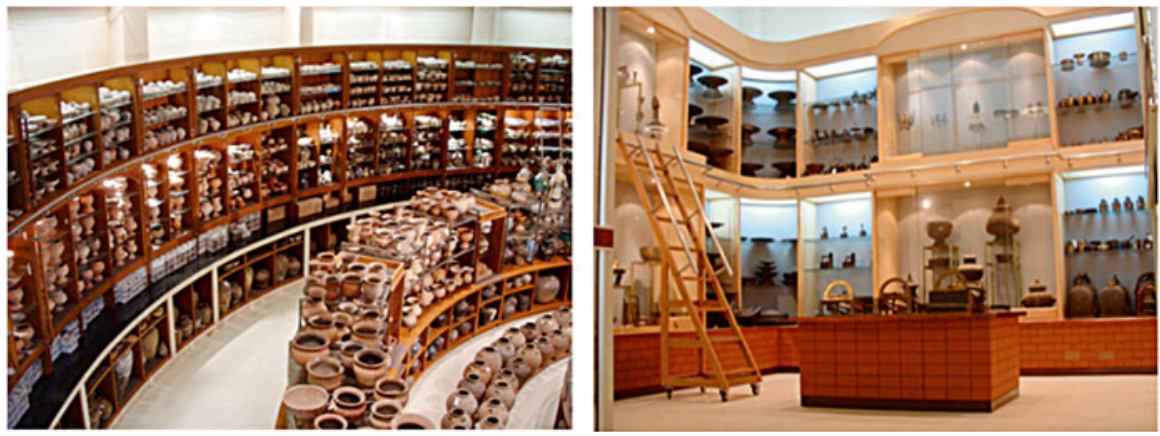

Fig. 8 Inside of the actual National Museum Storage in Pathumthani Province

Many national museums have attempted to change by themselves under limited conditions: contacting outsourcers, managing a youth museum guide, finding volunteers, creating museum souvenirs, and so on. Anyway, as mentioned before, this depends on each national museum's potentiality and readiness. It is very gratifying that many national museums, such as regional national museums and medium-scale museums like the Suphanburi National Museum, Ban Chiang National Museum, Roi-Et National Museum, Chiangsaen National Museum, and Surin National Museum have been established.

As for the policy level, this current time is very important for national museum management. To solve museum problems, the current Director General of the Fine Arts Department has announced his decision to reduce the number of national museums by transfer and combination. All of the small-scale national museums, formerly the monastery museums, have returned to being monastery museums, such as the Inburi National Museum in Singburi Province, Chainatmuni National Museum in Chainat Province, Matchimawat National Museum in Songkhla Province, Phra Phutthachinnarat National Museum in Phitsanulok Province, and Wat Benjamabophit National Museum in Bangkok.

To improve the image of national museums over the short term, there are three pilot projects. The first one is the establishment of seven national museum storage units to add a greater area for keeping huge numbers of ancient objects and art objects and also to develop storage management of a nearly universal standard. The first central storage unit, together with the Science Conservation Center in Pathumthani Province (Figs. 8 and 9), started this year, 2015, and there will be six more regional national museum storage units in Chiang Mai, Sukhothai, Khonkaen, Surin, Songkhla, and Nakhon Si Thammarat Provinces; of course, the storage buildings must be placed inside the national museum areas.

The second project is renovation of the National Museum Bangkok, following the master plan, for example, renovation of the old Palace Residences since the first Prince Successor and display inside each residence like its original function, and renovation of the permanent exhibition "Thai Civilization" inside these buildings. 

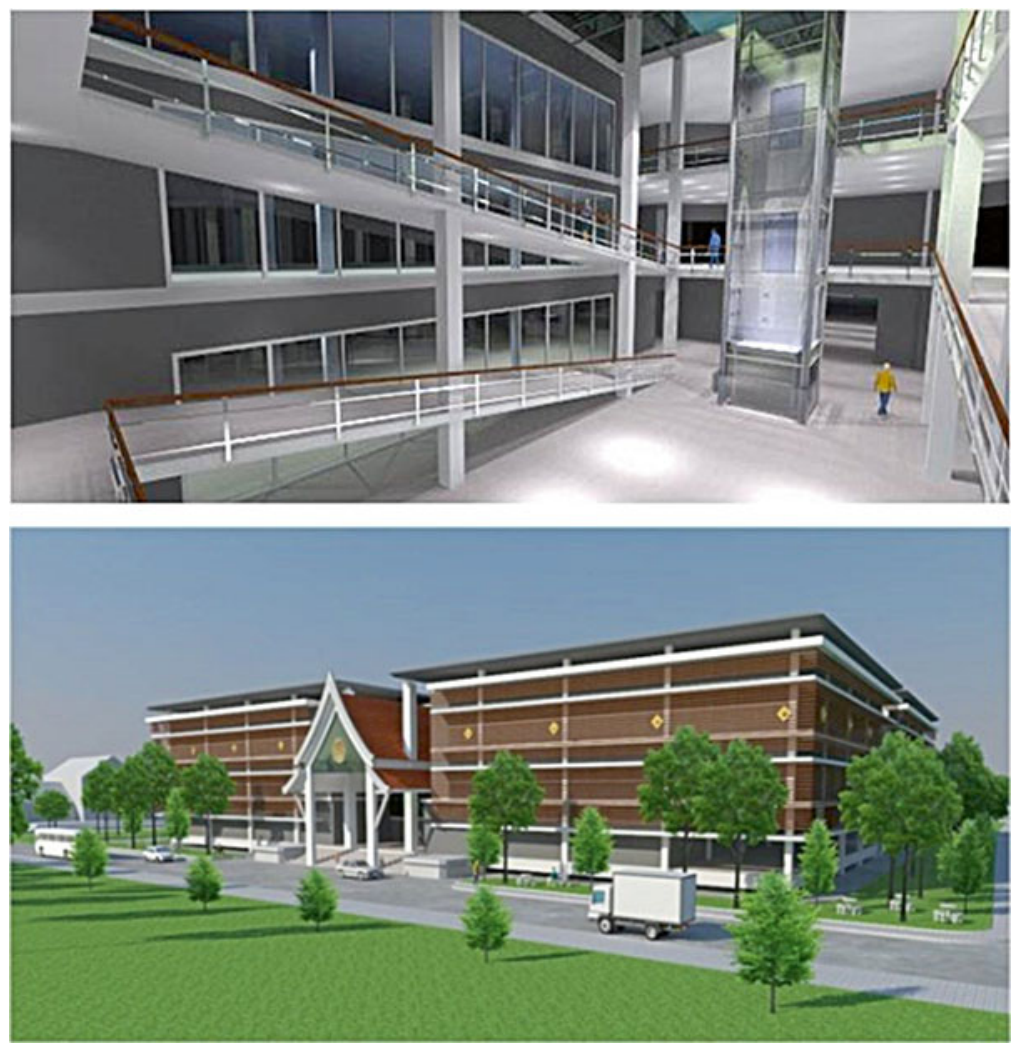

Fig. 9 A conceptual construction of a new central national museum's storage in Pathumthani Province

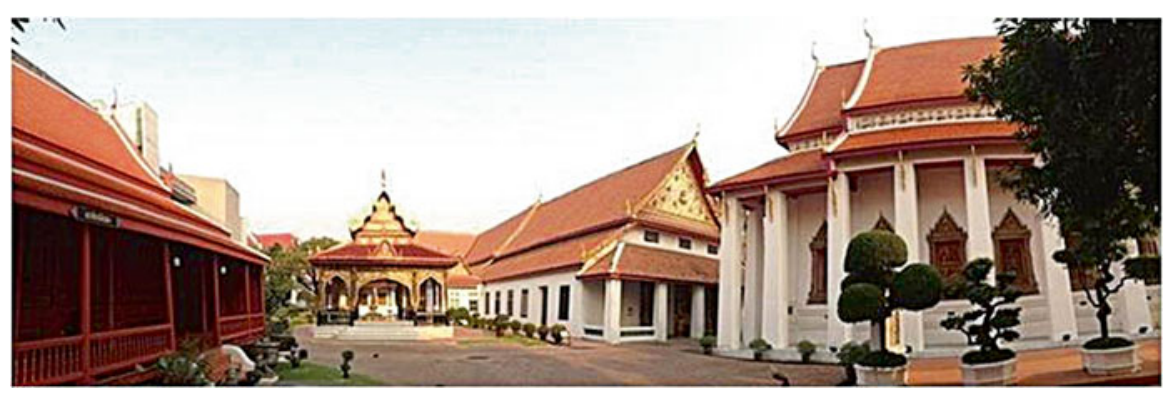

Fig. 10 National Museum Bangkok

Most of the collection comprises masterpieces that are very well known (Figs. 10 and 11).

And the last one is developing the Kanchanaphisek National Museum, the only ethnological national museum under the Fine Arts Department. Some national 


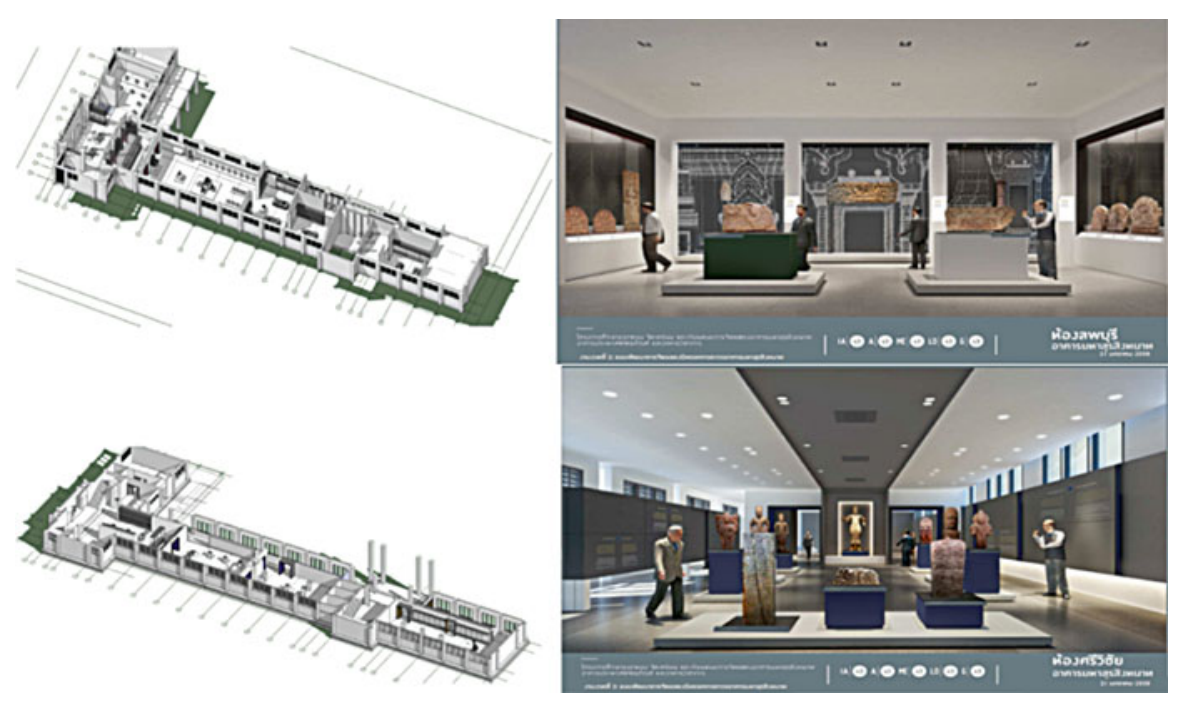

Fig. 11 Conceptual design of exhibition inside two buildings, National Museum Bangkok

museums in the provinces have ethnological sections in their gallery, with consideration given to ethnic people in the province and its surroundings. It is planned to intensively tell the story of all ethnic groups in Thailand at the Kanchanaphisek National Museum, under the titles "Window of Ethnology," "Way of Ethnographical Lives," and "Ethnographical Identity."

The museum consists of two buildings $\left(6,000 \mathrm{~m}^{2}\right)$ - central storage nowadays and an open area approx. of 79 rai $\left(126,400 \mathrm{~m}^{2}\right)$. The action plan for the development of the Kanchanaphisek National Museum, of which I am in charge, is into its fifth year: reconstruction of the old building; exhibition inside building no.1 (now storage for stone and large-size objects); setting up of an open-air "ethnographical architecture" exhibition; and renovation of building no. 2 (now storage for ethnographic and religious objects) and exhibition. It is planned to open the museum to the public after the exhibition in building no.1 and the open-air "ethnographical architecture" are finished.

\section{Conclusion}

In the world of museums everywhere, change is a very regular occurrence, especially changes to the administrative structure. The reduction in number of national museums is not a new matter. However, the changing of national museum management in Thailand during this time is not easy, but I eagerly anticipate these changes. 
Open Access This chapter is distributed under the terms of the Creative Commons AttributionNonCommercial 4.0 International License (http://creativecommons.org/licenses/by-nc/4.0/), which permits any noncommercial use, duplication, adaptation, distribution and reproduction in any medium or format, as long as you give appropriate credit to the original author(s) and the source, provide a link to the Creative Commons license and indicate if changes were made.

The images or other third party material in this chapter are included in the work's Creative Commons license, unless indicated otherwise in the credit line; if such material is not included in the work's Creative Commons license and the respective action is not permitted by statutory regulation, users will need to obtain permission from the license holder to duplicate, adapt or reproduce the material.

\section{References}

Fine Arts Department. 1974. Museums Management. Bangkok: The Religious Department Publishing. (Published in occasion of 100th Anniversary Celebrations of Museums in Thailand on 19 September 1974). (In Thai).

Fine Arts Department. 1993. King Rama VII and Museums Management in Thailand. Bangkok: Rungsilp Ltd. (Published in occasion of the 100th Anniversary of King Rama VII's Birthday). (In Thai).

Fine Arts Department. 1998. His Majesty the King of Thailand Kingdom and Museums Management. Bangkok: Graphic Format (Thailand), Ltd. (Published in occasion of The 50th Anniversary Celebrations of His Majesty's Accession To The Throne 1996). (In Thai)

Fine Arts Department. 2008. 149 Royal Museums. Bangkok: Union Ultra Violet Ltd. (Published in the occasion of The Sixtieth Anniversary Celebrations of King Bhumibol Adulyadej's Accession to the Throne 2006). (In Thai)

Office of National Museums, Fine Arts Department. 2006. The Directory of Museums in Thailand. Bangkok: Dok Bia Publishing. (In Thai). 